University of Minnesota Morris Digital Well

University of Minnesota Morris Digital Well

$10-2000$

\title{
Atheism and Sadism: Nietzsche and Woolf on Post-God Discourse
}

Michael Lackey

University of Minnesota Morris, lacke010@morris.umn.edu

Follow this and additional works at: https://digitalcommons.morris.umn.edu/eng_facpubs

Part of the Literature in English, British Isles Commons, and the Modern Literature Commons

\section{Recommended Citation}

Lackey, Michael. 2000. "Atheism and Sadism: Nietzsche and Woolf on Post-God Discourse." Philosophy and Literature 24.2: 346-363. doi:10.1353/phl.2000.0041

This Article is brought to you for free and open access by the Faculty and Staff Scholarship at University of Minnesota Morris Digital Well. It has been accepted for inclusion in English Publications by an authorized administrator of University of Minnesota Morris Digital Well. For more information, please contact skulann@morris.umn.edu. 


\title{
Atheism and Sadism: Nietzsche and Woolf on Post-God Discourse
}

\author{
Michael Lackey
}

This is an Accepted Manuscript of an article published by John Hopkins University Press in Philosophy and Literature in October 2000, available online: https://muse.jhu.edu/article/27045

"Modern consciousness is Godlessness....

I mean Godlessness in a strict sense." 1

In the western world, twentieth-century literature has been an extended experience of atheism and sadism. Lest this claim not seem dogmatic enough, let me put it differently, more boldly: this century has been an attempt to ingest and digest Nietzsche, to cannibalize the Übermensch philologist, first in order to comprehend the strength and depth of his vision, but second to enact his philosophy. ${ }^{2}$ Were this a standard academic essay, I would define atheism and sadism, identify and analyze a few texts that best corroborate my thesis, and draw some conclusions about the twentieth century. But sadism and atheism are not things to be defined, prediscursive conceptual entities waiting for the poet's or the scholar's turn of phrase to disclose their essences. In fact, atheism nullifies prediscursive truths and thereby alters the relationship language has to that which it signifies. ${ }^{3}$ In what follows, I bring atheism and sadism into a single constellation. By interacting with post-God writing, and by textualizing and intertextualizing sadism, I detail the radical shift in thought that Nietzsche articulated but that the twentieth century has lived.

\section{II}

"we could say that the death of

man links up with that of God."4

God's death leads to the death of the subject. Michel Foucault certainly draws this connection clearly enough when he claims that "God and man have died a common death," or that "it is not so much the absence or the death of God that is affirmed as the end of man." ${ }^{6}$ Not surprisingly, whenever Foucault announces the death of the subject, he specifically alludes to Nietzsche, for as Richard Schacht says of the German philosopher, the God-hypothesis and the subject-hypothesis are so inextricably linked that when one is undone, so too is the other. ${ }^{7}$ Jean-Paul Sartre arrives at a similar conclusion in Being and Nothingness when he tells us that "the passion of man is the reverse of that of Christ." For Sartre, if Christ lays aside his divinity by becoming human, then humans lay aside their humanity by constituting themselves as an "In-itself," an act "which escapes contingency by being its own foundation, the Ens causa sui, which religions call God." In other words, humans found themselves as an In-itself, as something metaphysical or divine, and in doing so, they lose their humanity "in order that God may be born." But since "the idea of God is contradictory," according to Sartre, humans lose themselves in vain. ${ }^{8}$ For this reason, Sartre insists that "there is no human nature, since there is no God to conceive it." "In "The Ends of Man," Derrida describes the situation thus: "What was named in this way, in an allegedly neutral and undetermined way, was nothing other than the metaphysical unity of man and God, 
the relation of man to God, the project of becoming God as the project constituting humanreality." 10 In each instance, human-reality presupposes the non-contingent reality of God, but since God has become a suspect concept, so too has the "human."

No doubt, we could find evidence of God's and the subject's common death as early as 1834 , but Virginia Woolf is one of the first to articulate clearly and consistently the consequences of atheism on subjectivity. ${ }^{11}$ While we could consider this idea in many of Woolf's works, I will focus my comments on Orlando and The Waves. To understand Woolf's critique of "God" and the church, it is important to note that two sets of binary oppositions are established in the opening pages of Orlando: Christian/Pagan, male/female. ${ }^{12}$ The novel begins with the young Christian--for there could be no doubt about his religion--"in the act of slicing at the head of a Moor." 13 Against the standard readings of this passage, I want to suggest that the narrator literally means, "there could be no doubt of his sex" or religion. ${ }^{14}$ With God in his heaven, all is right with essentialized subjects, so Orlando could playact the male, Christian role expected of a boy "whose father, or perhaps his grandfather, had struck it [the Moor's head] from the shoulders of a vast Pagan" (p. 13).

Before a radical questioning of binary oppositions could occur, the God-hypothesis would first have to be refuted, or at least challenged, and such a questioning did occur during the reign of King James (1603-25), the age in which Galileo's discovery of the telescope (1610) confirmed that the earth is not the center of the universe. The new world view forced God out of the Ptolemaic heavens and undermined the church's traditional belief in the hierarchical chain of being, leaving the seventeenth-century human beings with no justifiable ground for their established standing in the cosmos. So the church, which relinquished neither its power nor its teaching, had to assert itself more forcefully, lest humans fall prey to the "madness" (p. 46) of an undifferentiated universe.

Not coincidentally, Orlando meets Sasha when King James is in power (p. 31), and during a conversation with the young Russian, Orlando notes that only "a knife's blade separates" seeming contraries (p. 45). Because there is no legitimate ground for making clear categorical distinctions, the passage continues, the philosopher "bids us take refuge in the true Church ... which is our only harbour, port, anchorage, etc., he said, for those tossed on this sea" of a nondifferentiable world (p. 46). Indeed, the narrator goes out of his way to explain how Orlando's mind operates during the age of belief: "For that was the way his mind worked now, in violent seesaws from life to death stopping at nothing in between" (p. 46). As the novel progresses, however, and the clouds "darken[ed] and spread with extraordinary speed" "behind the dome of St. Paul's" (p. 225), and the age of doubt replaced the age of belief (p. 226), the core self disappears, and is replaced by many selves (pp. 308-9) which are ultimately thrown "into a metonymic confusion of genders." ${ }^{15}$ While Woolf scholars have recognized the radical consequences of Woolf's deconstruction of the subject in Orlando, they have yet to explain the link between God's death and the emergence of Orlando's many selves. So while a scholar like Susan E. Lorsch intelligently details how God's death leads to the designification of the landscape in Woolf's novels, she does not consider that Woolf's atheism directly leads to the designification of the "human." As for Pamela Caughie, though she rightly suggests that Orlando "challenges the reference theory of meaning" (VWP, p. 79) and articulates a total deconstruction of the subject, she does not consider the vital role Woolf's atheism plays in the subversion of the correspondence theory of truth. To understand Woolf's efforts to undo the 
bounded unity of an essentialized subject and the strict divisions of binary oppositions, we must take her atheism more seriously. According to such a reading, we would show how a gradual progression towards a world in which the reference theory of meaning is no longer tenable. So at the beginning of the novel, when the sea of faith is at the full, the bounded unity of a stable subject is firmly fixed, but as "God" and the church become less credible, "the reference theory of meaning" is undone, and subjectivity is liberated from the tyranny of essentialist discourses.

But let us look more closely at this idea as it contributes to our understanding of the novel. If, in the opening pages of the novel, Orlando is defined as male and Christian, his identity is single and stable. But when we come to the end of the novel, after Orlando has had an ambiguous sex change and has set himself off from the church, it should not be surprising that the narrator talks about a plurality of selves rather than a Captain self: "for everybody can multiply from his own experience the different terms which his different selves have made with him" (pp. 308-9). In a post-God age, when there is no longer an institution that serves as anchor and harbor for fixed essences and binary oppositions, discussion of the nature of reality no longer makes sense. So the novel, which begins with the construction of male/female and Pagan/Christian binary oppositions, closes by suggesting that "everything was partly something else, and each gained an odd moving power from this union of itself and something not itself so that with this mixture of truth and falsehood her [Orlando's] mind became like a forest in which things moved; lights and shadows changed, and one thing became another" (p. 323). If, as the logic of the novel suggests, the church functions to inscribe and legitimate conceptual distinctions, then the only way to allow one thing to become another would be to eliminate the difference-anchoring institutions-"God" and the church. Put differently, to develop a way of thinking that is not restricted to binary oppositions, Woolf suggests that God's death is necessary.

Understanding the link between God's death and the deconstruction of the subject effectively explains a consistent pattern in Woolf's novels. For Clarissa Dalloway, who "thought there were no Gods," ${ }^{16}$ subjectivity is "like a mist between the people she knew best" $(M D$, p. 9), while for Doris Kilman, the believer of Mrs. Dalloway, subjectivity is "a soul cut out of immaterial substance; not a woman, a soul" (p. 134). Similarly, in The Waves, Neville has a need "to offer" his "being to one god," 17 and not surprisingly, he has a tendency to contract "another person into a single being" (p. 89), whereas Bernard, who has no time for God or church (p. 242), experiences subjectivity as communal: "For this is not one life; nor do I always know if I am man or woman, Bernard or Neville, Louis, Susan, Jinny or Rhoda--so strange is the contact of one with another" (p. 281). For Woolf's believers, the human has a "Captain self" or a "Key self" $(O$, p. 310), but for the atheist, the idea of defining the "human" simply makes no sense, for the atheist's relationship to language results in the loss of a prediscursive conceptual reality. Though Caughie does not concern herself with Woolf's atheism, she states most clearly Woolf's post-God experience of language: "To speak of rhetoric as either revealing or concealing, to speak of appearance as either natural or contrived, is to set up a false opposition; it is to assume that we can get beyond or beneath the linguistic paradigm, in which rhetorical and sexual differences function, to some natural state, some natural discourse" (VWP, pp. 80-81). To the atheist, there can be no conceptual reality independent of language or the human, because there is no God to conceive it; so finding a discourse that best reflects reality is a senseless pursuit.

Interestingly, not all atheists responded to God's death by deconstructing the concept of reality. Put differently, there are various types of non-believers, and for the sake of clarity, I want 
to identify three distinctive groups, though I do not want to suggest that my taxonomy exhausts all possibilities. Let us begin with nihilism, a way of thinking that could easily be traced back to the famous Fichte/Jacobi debate. ${ }^{18}$ For the nihilist, after God's death everything is "nada y pues nada," to quote Hemingway. ${ }^{19}$ In the first half of the twentieth century, modernist writers and post-Husserlian phenomenologists commonly ontologized nothingness. For instance, Wallace Stevens suggests that once heaven is considered a tomb, we can look forward to a "spiritous passage into nothingness" ("Of Heaven Considered as a Tomb"), and by nothingness, he means that "[n]othing that is not there and the nothing that is" ("The Snow Man"). ${ }^{20}$ For phenomenologists, nothingness is a mystical but real presence as intense as the Platonic Good or the numinous God of the cloud of unknowing. Though Heidegger resists calling nothingness a "being" or an "object," he does use a totalizing category to uncover its distinctive qualities. While the traditional God is an "Absolute' [that] excludes all nothingness," he suggests that nothingness does have a prediscursive conceptual essence the nature of which humans must discover: "If the nothing itself is to be questioned as we have been questioning it, then it must be given beforehand. We must be able to encounter it." ${ }^{21}$ In the same tradition, Sartre draws heavily from Heidegger's essay as he outlines the phenomenological concept of nothingness in Being and Nothingness (pp. 16-45).

Another type of non-believer I refer to as the absurdist. For someone like Matthew Arnold, just because the "Sea of faith" has receded, this does not mean that humans are nihilistic blips waiting for extinction. However, according to the Arnold of "Dover Beach," since there is no God, there is no order to the universe, so there is no way to explain and/or alleviate the turbid ebb and flow of human misery. Put differently, the God-term is the unifying premise in the argument of life, but now that God is dead, life is a disordered and chaotic proposition where "ignorant armies clash by night." 22 Perhaps more than any other poem, T. S. Eliot's "The Waste Land" best embodies the absurdist position. Now that God is dead and "the empty chapel" is "only the wind's home," the universe can no longer be considered a coherent conceptual system, but rather, it is a "heap of broken images," and all myths are now nothing more than "withered stumps of time." 23 The fragmented structure of "The Waste Land," therefore, captures the essence of the post-God world as argument: disordered, fragmented, chaotic. Like the nihilist, life, for the absurdist, is an argument, and the task of the poet and the philosopher is to find a form that best reflects the fragmented reality of the world.

But for atheists like Nietzsche and Woolf, the idea of life as an argument (as an absolute reality, an absolute absurdity, or an absolute nothing) simply makes no sense, because there is no prediscursive reality, uttered by a divine speaking being, waiting to be discovered. Put differently, nihilists and absurdists contradict themselves, because they presuppose that there is a conceptual reality that humans can discover, a reality created by God, a reality that is God. This is exactly what Kafka had in mind when he told Max Brod, "We are nihilistic thoughts that came into God's head." "24 To be absolutely nothing in a Heideggerian or Sartrean sense, God must have spoken humans ("nihilistic thoughts") into existence; therefore, nihilism presupposes God. For atheists like Nietzsche and Woolf, by contrast, "Life is no argument." ${ }^{25}$ Therefore, the atheist can only be experienced as non-definable energy confronting adiscursive forces. To understand this non-believer as non-definable "energy," let me show how a Nietzschean atheist differs from a Sartrean nihilist. According to Sartre, the existentialist lives in anguish and despair, because there is no God: "The existentialist . . . thinks it very distressing that God does not exist, because all possibility of finding values in a heaven of ideas disappears along with 
Him; there can no longer be an a priori Good, since there is no infinite and perfect consciousness to think it" ("HE," p. 40). Notice how Sartrean existentialists define themselves in relation to a preexistent ideal. In this instance, existentialists are only an afterthought, the conceptual refuse of the Platonic Ideal---this explains why Sartre refers to the human as "a useless passion" ( $B N$ p.615). In a sense, Sartre's existentialists have conceded to the faithful, defining themselves in relation to the reigning absolute. Nietzsche's atheist, by contrast, could not despair on discovering that God does not exist, because the question of a prediscursive ideal simply makes no sense. In other words, despairing because there is no God is like despairing because there is no Great Pumpkin or a unicorn.

This explains the difference between Nietzsche's and Sartre's atheism. Though Sartre endorses an active philosophy of self-creating and self-transcending, similar to Nietzsche's philosophy of self-overcoming, Sartrean humans will never rise to the level of the metaphysical ideal--they are doomed to a life of contingency. Therefore, their being, in relation to the grand Ideal, can only be irrelevance, insignificance, and death. Not so for atheists like Nietzsche and Woolf. Zarathustra says: "what would there be to create if gods--existed!"26 For the atheist, because life is no argument, "human" value and worth are not determined through perceiving the highest realities: God, metaphysics, Truth, etc. On the contrary, in a post-God age, such "realities" are only the seething product of an overheated imagination. Therefore, the atheist's virtue is creation. But whereas creating self will always result in despair for Sartre's existentialist, because humans can never create themselves beyond contingency, the atheist does not use a metaphysical or noncontingent ideal as the touchstone for determining the worth of an individual's self-generating act. In the tradition of Nietzsche, therefore, atheists cannot be defined; they are iconoclasts and logoclasts, not because they relish destruction, but because they experience "themselves" as a site for limitless possibilities; language for the atheist is not primarily a tool for communication, though it sometimes can have that function, but an occasion for experiment, expansion, becoming, for creating something beyond the "human" or outside the "human." Atheists renounce being, and most specifically their own being. The effect of atheism on language is profound. ${ }^{27}$

\section{III}

"Gloomy grammarian in golden gowns,

Meekly you keep the mortal rendezvous,

Eliciting the still sustaining pomps

Of speech which are like music so profound

They seem an exaltation without sound." 28

Using language presupposes an act of sadism. In a sense, this is what Foucault has in mind in "The Discourse on Language." Whereas the world once stood before us like a sacred hieroglyph, harboring ancient truths, safeguarding Godly wisdom, it now stands shrouded in an adiscursive silence, neither welcoming nor repulsing human systems of signification, but indifferent to language, humans, and truth. "We must conceive discourse," consequently, "as a violence that we do to things, or, at all events, as a practice we impose upon them." ${ }^{29}$ No doubt, we can easily detect Foucault's debt to Nietzsche in this sentence. For Nietzsche, language is a violent act of taking possession of that which is named: "The lordly right of giving names extends so far that one should allow oneself to conceive the origin of language itself as an expression of power on 
the part of the rulers: they say 'this is this and this,' they seal every thing and event with a sound and, as it were, take possession of it." ${ }^{30}$ While Kaufmann's translation here is adequate, a close look at the original German makes the claim somewhat stronger. The last part of the passage reads: "sie siegeln jegliches Ding und Geschehen mit einem Laute ab und nehmen es dadurch gleichsam in Besitz." ${ }^{31}$ Kaufmann was right to translate the verb siegeln into the verb seal, but in English, the separable prefix, $a b$, gets lost in translation. When naming an object, lordly rulers seal that which they name, yet in German, the claim is stronger because the act of giving a seal implies a sealing off such that the named object disallows naming from other quarters, and it is the non-standard separable prefix, $a b$, which functions to highlight this sealing-off activity. Granted, the act of affixing a seal to an object can imply exclusive rights to the sealed object, but the German, siegeln . . a ab, highlights this point more forcefully. So when individuals name an object, they take exclusive possession of it, because they prevent others from naming the object as well.

Given this view of language, when we "know," let us say, the human as a being endowed with an ego, an id, and a superego, what we "know" is a Freudian version of the self, and not the self as such, and if we blindly accept Freud's view of the self, we have allowed him to take possession of us. In Twilight of the Idols, Nietzsche discusses the process whereby the "inner world" is populated with "phantoms and false lights," suggesting in fact that consciousness and the ego are nothing more than a "fable, a fiction, a play on words." 32 To understand verbal projections as the thing in itself is to mistake beliefs for reality, and since Nietzsche considers belief "slavery in a higher sense," 33 the "seduction by grammar" 34 becomes exactly that which enables the lordly rulers of language to take possession of individuals. This explains why Nietzsche thought knowledge of self a naive and unrealizable project ${ }^{35}$--from the moment we enter into the community of language and values, we become physiologically false because we adopt, unconsciously, involuntarily, the words and moralities of the community. ${ }^{36}$

While Woolf, like most writers, had a pathological relationship with words throughout her career, it was only from 1928 to 1931 that she finally began to abandon, in whole, the correspondence theory of truth and to see that life is no argument. Consequently, instead of seeing language as a tool for giving us access to or at best reflecting the "reality" of the world, the Woolf of the late 1920s claims that "discourse produces the effects that it names," 37 to quote Judith Butler. The character, Neville, from The Waves, best expresses this understanding of language when he claims: "Nothing should be named lest by so doing we change it" (p. 81). For Woolf, to be is to be named; so when humans verbally interact with one another, there is always the danger of taking conceptual possession of the other, of subjecting the other into grammatical being through one's own verbal will to power. In The Waves, Neville and Bernard are the two characters who understand this uncanny power of language most clearly. When reflecting on the complexity of one's own coming-to-be as a subject, Bernard takes note of the dangers of language and perception as he discovers the role others play in his genesis as a subject: "To be myself (I note) I need the illumination of other people's eyes, and therefore cannot be entirely sure what is my self' (p. 116). Without the look of the other, Bernard cannot come to know himself, and yet, in the moment he confers on others the power to illuminate his own subjectivity, he becomes subject to the formative power of the other's look.

To see exactly how discourse and perception function to subject others into being, let us look specifically at Neville's interaction with those around him. Neville is a poet. Significantly, his 
poetry is used as a weapon, something he flings at people. In fact, at one point he likens his poetry to a bullet: "The desire which is loaded behind my lips, cold as lead, fell as a bullet, the thing I aim at shop-girls, women, the pretence, the vulgarity of life . . . shoots at you as I throw-catch it--my poem" (p. 88). Later, in a brief exchange with Bernard, Neville says: "I took my poem, I flung my poem, I slammed the door behind me" (p. 126). As an art form, poetry is used to afflict others; it is a culturally sanctioned way to inflict violence on the world, and as a poet, Neville makes an art of doing violence to the world and others.

Granted, Neville is the most despicable character in the novel; so we should resist valorizing his aesthetic. Yet, without the seductive power of poetic visionaries like Neville, we would not be able to order world phenomena, for as Woolf makes clear, those who cannot adopt or create a vision, like Rhoda, cannot survive. So even though naming the world entails an act of epistemic violence, Woolf does not suggest that we stop naming or banish the poets. For Woolf, despite Neville's tyrannical disposition, his poetry provides us with a compelling vision of the world. Bernard discovers this late in the novel when Neville gives him a perceptual framework for perceiving a scene along the river: "The scene was cut out with such intensity," says Bernard, "and so permeated with the quality of [Neville's] vision that for a moment I could see it too" ( $p$. 251). Though life and the world may be no argument, Neville's poetic vision allows Bernard to see in it an order, a meaning, something stable. Of course, Bernard will eventually realize that such a vision "is a mistake, this extreme precision, this orderly military progress; a convenience, a lie" (p. 255), but it is a necessary lie, one without which we could not survive.

Though Neville inflicts violence on the world when he names it, this violence is most extreme when he flings his poems at a person. Bernard makes this discovery after reading a friendship poem Neville wrote for him. For Bernard, who normally thinks of himself as multiple and complex, the idea of being a single self makes no sense. But Neville, who has a need to reduce complexity to something simple and orderly, believes that Bernard is only one person: himself. Indeed, in his poem, Neville tells his friend exactly this, to which Bernard replies: "To be contracted by another person into a single being--how strange" (p. 89). Neville's vision, housed in his poem, literally has the power to contract Bernard into a single and unified being; it has the power to materialize Neville's will to power in the body of his friend. Woolf's decision to use the word contract highlights the power of the poetic word. As a legal word, contract indicates Bernard's condition as a political subject--the social or political contract recognizes him as a single self. As a poetic word, contract underlines the power poetry has to materialize a reality within the body of another. Taken together, the word suggests the political power of the poetic word to control a person's genesis within the context of the body politic.

Like Neville, Bernard is also a writer, yet he does not have the same propensity to use language as a weapon or a tool for subjecting another into grammatical being. Or so it would seem. As an artist, Neville represents the most blatant example of poetic imperialism, a person who uses language to evangelize and colonize the other, and while Bernard consciously distances himself from Neville's colonizing impulse, he learns that he too cannot avoid this tendency. In a passage reminiscent of the conclusion of Joyce's A Portrait of the Artist as a Young Man, Bernard revels in his plastic power: "We are not sheep either, following a master. We are creators. ... We too, as we put on our hats and push open the door, stride not into chaos, but into a world that our own force can subjugate and make part of the illumined and everlasting road" (p. 146). At this juncture, Bernard is not too far off from Neville, but more importantly, if we 
understand that language can contract a person into grammatical being, then Bernard's impulse to "subjugate" can have enormous consequences on those with whom he interacts. That he has the power to create another Bernard makes clear when he tells Neville: "Let me then create you. (You have done as much for me)" (p. 85).

Here we come to the crucial part of my argument. For Bernard, Neville's impulse to use language to colonize the other is a profound violation of the other, and while Bernard decides to use language in the same way when he interacts with Neville, he normally tries to avoid such colonizing. For instance, he berates himself for letting "fly my tremendous battery of phrases upon somebody quite inappropriate" (pp. 249-50). For Bernard, however, what is at stake is not the conscious attempt to subject another person into grammatical being, but the subconscious will to power, that undetectable yearning to use language as a tool for creating order out of chaos, for systematizing the unsystematizable, for making life an argument. In a moment of profound awareness, Bernard asks himself: "But why impose my arbitrary design?" (p. 188). The answer to this question is hard to accept. On a conscious level, there is no reason to do so, but on a subconscious level, there are two reasons why imposing an arbitrary design is unavoidable. First, to create is to subjugate, so to construct a language game would be to contract the other. As an artist and a creator, indeed, as a language user, Bernard must subject others into grammatical being, for the moment we enter into language, we perform an act of epistemic violence on that which we name. And as Bernard makes clear in the language of Stephen Dedalus, such creation is an act of profound joy. Put differently, our creative joy is essentially linked to poetic violence, the violence we do to the world, the violence we do to each other. Poetry is sadism.

Second, embedded within culture and language, we are the involuntary carriers of other people's wills to power. Bernard is insightful on this score: "It is curious how, at every crisis, some phrase which does not fit insists upon coming to the rescue--the penalty of living in an old civilisation with a notebook" (p. 184). The "penalty" of existence is to be "physiologically false." Wills to power, effectively concealed in the guise of language and values, insidiously work their way into our bodies, encoding us, whether we know it or not, so that we become the involuntary carriers of another civilization's system of living. Having been interpellated, in an Althusserian sense, we then use this specific language game to name those in our vicinity (using "some phrase which does not fit" the current situation). In other words, one of the culture's dominant ideologies, which enacts its algorithmic logic within our bodies, is what we in turn use to subject others into grammatical being. To think that one could evade such a situation would be to suggest that we could stand outside language and culture, and Woolf, a woman who did not believe in God, a transcendental ego, or a metaphysical subject, certainly does not entertain such a possibility.

For Woolf, then, to use language is to be a sadist, and the more attached we are to words, the more skillfully we use them, the more intense will be our sadistic pleasure. Does this mean that we should grow less attached to words or abandon poetic language? On the contrary, Woolf suggests that we energize cultural contact and human relations, not by denying the existence of the colonizing impulse, but by incorporating it into a productive relation to the other. In a rare moment of freedom and intimacy, Bernard and Neville use language to create and subjugate each other, to experience a coercive intimacy, a mutual colonization within the context of the poetic contract. When reflecting on the power a Shakespeare has on them, or even the power an old 
woman named Peck might have on them, Bernard and Neville abandon their first-person singular discourse as they merge into the first-person plural: "So we shared our Pecks, our Shakespeares; compared each other's versions; allowed each other's insight to set our own Peck or Shakespeare in a better light; and then sank into one of those silences which are now and again broken by a few words, as if a fin rose in the wastes of silence; and then the fin, the thought, sinks back into the depths spreading round it a little ripple of satisfaction, content" (p. 273). As wordsmiths, these two use language to subjugate each other, and in this instance, they allow each other's insights to set their own Peck or Shakespeare in a better light. In other words, they do not avoid the colonizing impulse. Consequently, by making a momentary agreement to colonize each other, two new "selves" emerge. This moment, however, does come to an abrupt end, not just because Neville, the believer, resorts to a ruthless form of subjugating Bernard, but mainly because he violates the colonizing ethic of intimacy; he refuses to allow Bernard to colonize him. Bernard notices this and responds accordingly: "everything became definite, external, a scene in which I had no part. I rose, therefore; I left him" (p. 274). As a writer, Bernard has a desire to create, to subjugate; he wishes to form that hazardous and marvelous space of intimacy. But as soon as Neville refuses to honor the aesthetic contract, Bernard can no longer experience a poetic joy. So he leaves.

\section{IV}

"Now that my ladder's gone,

I must lie down where all the ladders start, In the foul rag-and-bone shop of the heart." 38

In his recent book God and the American Writer, Alfred Kazin makes an astonishing claim. He argues that we Americans are, whether we admit it or not, atheist to the core, that belief in God is no longer possible for us. ${ }^{39}$ Ironically, atheism is still a taboo topic. Because of the demonization of nonbelievers--they cannot be moral (Fyodor Dostoevsky); they cannot love (Aldous Huxley); they cannot lead meaningful lives (Flannery O'Connor)--overt atheistic gestures are generally rejected. It is interesting to note that book-length studies have been done on Woolfian androgyny, though there are only a handful of references to the concept in her works, while there has been no extended analysis of Woolf's atheism, even though the topic appears in every novel and almost every short story. Given the demonization of the atheist, it is no surprise that the discourse has gone underground. However, while Deleuze, Derrida, Butler, Guattari, Kofman, Mouffe, and others rarely address atheism directly, it is my contention that their works take as a starting point Nietzsche's and Woolf's atheistic philosophy of language. In other words, I claim that these writers are atheists who understand language as an exercise in sadism.

Starting with Gilles Deleuze's 1962 book Nietzsche \& Philosophy, the turn towards atheism-in terms of language--had begun. Making a decisive break with existentialist misreadings (Heidegger's, Jaspers's, and Kaufmann's), Deleuze says of Nietzsche's philosophy: “A phenomenon is not an appearance or even an apparition but a sign, a symptom which finds its meaning in an existing force. The whole of philosophy is a symptomatology, and a semeiology." 40 These two sentences best articulate what would become for philosophers and literary, cultural and political theorists the central focus of investigation for now more than thirty years. Derrida's “Deconstruction is justice," Deleuze and Guattari's "rhizome as subterranean 
stem," Mouffe's political pluralism, Althusser's interpellation thesis, Butler's subversion of gender and sex,${ }^{41}$ the list could go on--all of these writers have one thing in common: their debt to Nietzsche's post-God theory of language. We have only now begun to address the consequence of de-divinizing language, even if the scholarly community refuses to acknowledge that this is what it is doing. ${ }^{42}$ But should we ever begin the process of making an honest and genuine interrogation of our western tradition's turn towards atheism, perhaps we would then begin to understand the sadistic basis of language. And should we go this next step, who knows, perhaps Nietzsche will have turned out to be more prophetic than any of us would have ever suspected: "It is only beginning with me that the earth knows great politics." 33

${ }^{1}$ Richard Wright, The Outsider (San Francisco: Harper Collins, 1993), p. 274.

${ }^{2}$ By cannibalization, I am referring to Freud's theory of identification, which he defines as "the assimilation of one ego to another one, as a result of which the first ego behaves like the second in certain respects, imitates it and in a sense takes it into itself. Identification has been not unmistakably compared with the oral, cannibalistic incorporation of the other person." Sigmund Freud, New Introductory Lectures on Psycho-Analysis, trans. James Strachey (New York: W. W. Norton \& Company, 1989), pp. 78-79.

${ }^{3}$ Michel Foucault makes a similar claim: more than anything else, "the death of God profoundly influenced our language." Michel Foucault, "The Father's No," Language, Counter-Memory, Practice: Selected Essays and Interviews, trans. Donald F. Bouchard and Sherry Simon (Ithaca: Cornell University Press, 1977), pp. 85-86. For additional studies that examine the effect of atheism on language, see Jacques Derrida, "Force and Signification" and "The Theater of Cruelty and the Closure of Representation," in Writing and Difference, trans. Alan Bass (Chicago: University of Chicago Press, 1976), pp. 3-30; 232-50; Of Grammatology, trans. Gayatri Chakravorty Spivak (Baltimore: Johns Hopkins University Press, 1976); Michel Foucault, "A Preface to Transgression," Language, Counter-Memory, Practice: Selected Essays and Interviews, pp. 29-52; and Richard Rorty, Contingency, Irony, and Solidarity (Cambridge: Cambridge University Press, 1989), pp. 3-22.

${ }^{4}$ Gilles Deleuze, Foucault, trans. Sean Hand (Minneapolis: University of Minnesota Press, 1986), pp. 88-89.

${ }^{5}$ Michel Foucault, "What is an Author?" The Foucault Reader, ed. Paul Rabinow (New York: Pantheon Books, 1984), p. 105.

${ }^{6}$ Michel Foucault, The Order of Things: An Archaeology of Knowledge, trans. A. M. Sheridan Smith (New York: Random House, 1970), p. 385.

${ }^{7}$ Schacht says: "It may be observed, in this connection, that Nietzsche considers these two hypotheses to be intimately connected--the soul-hypothesis leaning upon the God-hypothesis for its philosophical and theological intelligibility, and the God-hypothesis leaning upon the soulhypothesis for much of its evidence and intuitive appeal." Richard Schacht, Nietzsche (New York: Routledge, 1985), p. 131. 
${ }^{8}$ Jean-Paul Sartre, Being and Nothingness, trans. Hazel E. Barnes (New York: Philosophical Library, 1956), p. 615, hereafter abbreviated in the text as $B N$.

9 Jean-Paul Sartre, "The Humanism of Existentialism," Essays in Existentialism (Secaucus, New Jersey: Carol Publishing Group, 1999), p. 36, hereafter abbreviated as "HE."

${ }^{10}$ Jacques Derrida, "The Ends of Man," Margins of Philosophy, trans. Alan Bass (Chicago: University of Chicago Press, 1982), p. 116.

${ }^{11}$ In 1834, Heinrich Heine concludes section two of Philosophy and Religion in Germany with God's death, an event that necessarily follows, at least according to Heine, from Kant's philosophy. Section three, therefore, begins with a secular creation story. Too little attention has been paid to Heine's remarkable contribution to the dialogue concerning God's death and the subsequent deconstruction of the subject. Heinrich Heine, Philosophy and Religion in Germany, trans. John Snodgrass (Boston: Beacon Press, 1959).

${ }^{12}$ For discussions of Woolf's atheism, see Susan E. Lorsch, Where Nature Ends: Literary Responses to the Designification of the Landscape (London: Associated University Presses, 1983), pp. 13-27; 132-149; Mark Hussey, The Singing of the Real World: The Philosophy of Virginia Woolf's Fiction (Columbus: Ohio State University Press, 1986), pp. 96-106; Martin Corner, "Mysticism and Atheism in To The Lighthouse," Studies in the Novel 13 (1981): 408-23; and Makiko Minow-Pinkney, "'How then does the light return to the world after the eclipse of the sun? Miraculously, frailly': A Psychoanalytic Interpretation of Woolf's Mysticism," Virginia Woolf and the Arts, eds. Diane F. Gillespie and Leslie K. Hankins (New York: Pace University Press, 1997), pp. 90-97.

${ }^{13}$ Virginia Woolf, Orlando: A Biography (New York: Harcourt Brace, 1956), p. 13, hereafter abbreviated as $O$.

${ }^{14}$ Pamela Caughie argues that "our doubt is aroused" about Orlando's sex because, in calling attention to his sex, the "stress on what is obvious makes it seem unnatural. The stress on an innocent pronoun makes it suspect." Pamela Caughie, Virginia Woolf \& Postmodernism:

Literature in Quest \& Question of Itself (Urbana: University of Illinois Press), p. 78, hereafter abbreviated as $V W P$. Minow-Pinkney argues along similar lines, but she focuses on the text's obsession with disguise. Makiko Minow-Pinkney, Virginia Woolf \& the Problem of the Subject (New Brunswick: Rutgers University Press, 1987), p. 132.

${ }^{15}$ Makiko Minow-Pinkney, p. 122.

${ }^{16}$ Virginia Woolf, Mrs. Dalloway (New York: Harcourt Brace, 1981), p. 78, hereafter abbreviated as $M D$.

${ }^{17}$ Virginia Woolf, The Waves (New York: Harcourt Brace, 1959), p. 52, hereafter abbreviated as $T W$.

${ }^{18}$ For a useful discussion of the Fichte/Jacobi debate, see Daniel Breazeale, "Fichte in Jena," Fichte: Early Philosophical Writings, ed. Daniel Breazeale (Ithaca: Cornell University 
Press, 1988), pp. 1-46. I would like to thank Dan for helping me clarify the evolution of nineteenth-century nihilism.

${ }^{19}$ Ernest Hemingway, “A Clean, Well-Lighted Place," The Short Stories of Ernest Hemingway (New York: Charles Scribner's Sons, 1966), p. 383.

${ }^{20}$ Wallace Stevens, The Collected Poems of Wallace Stevens (New York: Vintage Books, 1982), pp. 56; 10.

${ }^{21}$ Martin Heidegger, "What is Metaphysics?" Martin Heidegger: Basic Writings, ed. David Farrell Krell (San Francisco: Harper \& Row, 1977), pp. 104; 110; 100.

${ }^{22}$ Matthew Arnold, Poetry and Criticism of Matthew Arnold, ed. A. Dwight Culler (Boston: Houghton Mifflin Company, 1961), pp. 161-62.

${ }^{23}$ T. S. Eliot, "The Waste Land," The Complete Poems and Plays: 1909-1950 (New York: Harcourt, Brace and Company, 1958), lines 389; 22; 104.

${ }^{24}$ Max Brod, Franz Kafka: A Biography (New York: Schocken Books, 1963), p. 75.

${ }^{25}$ Friedrich Nietzsche, The Gay Science, trans. Walter Kaufmann (New York: Random House, 1989), p. 177, hereafter abbreviated as $G S$.

${ }^{26}$ Friedrich Nietzsche, Thus Spoke Zarathustra, trans. R. J. Hollingdale (New York: Viking Penguin, 1969), p. 111.

${ }^{27}$ For a more extensive analysis of the effect of atheism on the death of the subject, see my essay, "Killing God, Liberating the 'Subject': Nietzsche and Post-God Freedom," Journal of the History of Ideas 60 (1999): 737-54.

${ }^{28}$ Wallace Stevens, The Collected Poems of Wallace Stevens (New York: Vintage Books, 1982), p. 55.

${ }^{29}$ Michel Foucault, "The Discourse on Language," The Archaeology of Knowledge, trans. A. M. Sheridan Smith (New York: Pantheon Books, 1971), p. 229.

${ }^{30}$ Friedrich Nietzsche, On the Genealogy of Morals, trans. Walter Kaufmann (New York: Random House, 1989), p. 26.

${ }^{31}$ Friedrich Nietzsche, Kritische Gesamtausgabe: Werke, ed. Giorgio Colli and Mazzino Montinari, 30 vols. (Berlin: de Gruyter, 1967-1978), vol. 5, p. 260.

${ }^{32}$ Friedrich Nietzsche, Twilight of the Idols, trans. R. J. Hollingdale (New York: Viking Penguin, 1990), p. 59. Nietzsche also develops this point in GS, pp. 297-300.

${ }^{33}$ Friedrich Nietzsche, The Antichrist, trans. R. J. Hollingdale (New York: Viking Penguin, 1990), p. 182. 
${ }^{34}$ Friedrich Nietzsche, Beyond Good and Evil, trans. Walter Kaufmann (New York: Random House, 1966), p. 2.

${ }^{35}$ See Friedrich Nietzsche, Ecce Homo, trans. Walter Kaufmann (New York: Random House, 1974), pp. 253-55; On the Genealogy of Morals, p. 15.

${ }^{36}$ Nietzsche makes this point brilliantly in the "Epilogue" of The Case of Wagner: "All of us have, unconsciously, involuntarily in our bodies, values, words, formulas, moralities of opposite descent--we are, physiologically considered, false." Friedrich Nietzsche, The Case of Wagner, trans. Walter Kaufmann (New York: Random House, 1967), p. 192.

${ }^{37}$ Judith Butler, Bodies That Matter: On the Discursive Limits of 'Sex' (New York: Routledge, 1993), p. 2.

${ }^{38}$ William Butler Yeats, "The Circus Animals' Desertion," The Variorum Edition of the Poems of W. B. Yeats, ed. Peter Allt and Russell K. Alspach (New York: Macmillan, 1966), p. 630.

${ }^{39}$ Alfred Kazin, God and the American Writer (New York: W.W. Norton and Company, 1999).

${ }^{40}$ Gilles Deleuze, Nietzsche \& Philosophy, trans. Hugh Tomlinson (New York: Columbia University Press, 1983), p. 3.

${ }^{41}$ Jacques Derrida, "Force of Law: The 'Mystical Foundation of Authority,"“ Deconstruction and the Possibility of Justice, eds. Drucilla Cornell, Michael Rosenfeld, and David Gray Carlson (New York: Routledge, 1992), p. 15; Gilles Deleuze and Felix Guattari, A Thousand Plateaus: Capitalism and Schizophrenia, trans. Brian Massumi (Minneapolis: University of Minnesota Press, 1987), p. 6; Chantal Mouffe, "Democracy, Power, and the 'Political,"“ Democracy and Difference: Contesting the Boundaries of the Political, ed. Seyla Benhabib (Princeton: Princeton University Press, 1996), pp. 245-55; Louis Althusser, "Ideology and Ideological State Apparatuses (Notes towards an Investigation)," Mapping Ideology, ed. Slavoj Zizek (London: Verso, 1995), pp. 100-138; Judith Butler, Bodies That Matter: On the Discursive Limits of 'Sex.'

${ }^{42}$ This phrase, de-divinization, I borrow from Rorty: "To drop the idea of languages as representations, and to be thoroughly Wittgensteinian in our approach to language, would be to de-divinize the world." Richard Rorty, Contingency, Irony, and Solidarity, p. 21.

${ }^{43}$ See Friedrich Nietzsche, Ecce Homo, p. 327. 